\title{
Assessing Polyembryony among Jamun (Syzygium cumini Skeels.) Collections
}

\author{
A. Rekha ${ }^{1}$, H. D. Talang ${ }^{2 *}$ and Anuradha Sane ${ }^{1}$ \\ ${ }^{1}$ Division of Fruit Crops, ICAR-Indian Institute of Horticultural Research, \\ Bengaluru-560 089, India \\ ${ }^{2}$ Division of Horticulture, ICAR Research Complex for NEH Region, Umiam-793 103, India \\ *Corresponding author
}

Ke y w o r d s
Jamun,
polyembryony,
multiple seedlings,
Eco regions

\section{Introduction}

Jamun (Syzygium cumini Skeels.) is an important indigenous fruit of India. It belongs to the family Myrtaceae. It is native to India and Myanmar, however, it has naturalized throughout the South East Asia and Pacific regions. Polyembryony is a condition in which multiple embryos arise within the embryo sac by budding or by cleavage of the zygotic pro-embryo or from the synergids and antipodal cells (Maheswari and Sacher, 1963). Adventitious embryos are initiated directly from the maternal nucellar tissue, which surround the embryo sac containing a developing zygotic embryo (Aleza et al., 2010). This phenomenon is more common in gymnosperms (Ensign, 1919). Polyembryony is a common phenomenon in number of fruit crops like Mango, Citrus, Jamun and so on. 
The maximum number of embryos observed in jamun was four (Sivasubramaniam and Selvarani, 2012).

Variations in the polyembryonic status was observed in different cultivars/ varieties/ species which was attributed to environmental conditions, physiological status of the plant, availability of pollen, position of fruit on the tree and also genetic, where it is said to be controlled by dominant gene with heterozygous allele. The degree of polyembryony can be low, medium and high (Kishore, 2014). Lakshmanan and Ambegaokar (1984) have described that Polyembryony can be of four types which was mentioned by Braun as early as 1859; namely 1) Fusion of more than one ovules 2) Several embryo sacs in the nucellus of the same ovule 3) Embryo development of other cells of the same embryo sac and 4) Division of proembryo. It can also be induced due to chemical treatment and multiple embryos emerge in in vitro plants. Such embryos are often asexual. The seeds may be polyembryonic but all the embryos do not germinate (Sivasubramaniam and Selvarani, 2012). Rate of polyembryony was also observed to be varying from seed to seed, fruit to fruit, sector to sector and from year to year in the same plant (Soares Filho et al., 1995). Number of seedlings produced in a polyembryonic seed also depends on other parameters like seed weight, seed length and seed girth (Ochoa et al. 2012).

\section{Materials and Methods}

Under the germplasm collection program at ICAR-IIHR, explorations were undertaken in different states like Karnataka, Andhra Pradesh, Gujarat, Uttar Pradesh, Madhya Pradesh, Jharkhand and other local areas. The other local collections involved the seeds collected from different markets and also North Eastern state of Nagaland. The fruits were collected randomly from different regions and various collection sites between the years 2012-2017. They were brought to ICAR-IIHR, Bengaluru washed thoroughly and ten seeds of each accession were sown in pro-trays containing cocopeat in the Division of Fruit Crops nursery. Number of seedlings germinated was counted thirty days after sowing. The percent polyembryony was calculated based on number of seedlings produced per seed. A total of 1658 seeds were observed. Correlations between seed characters and polyembryony were calculated as per Pearson Correlation Coefficients $\mathrm{N}=$ 35 Prob > $|\mathrm{r}|$ under H0: Rho=0 using SAS version

\section{Results and Discussion}

A total of 919 seeds were evaluated for percent polyembryony based on the number of embryos a seed produced. The percent seedlings produced varied from 55.43\% where a single seedling was obtained and $0.06 \%$ of the seeds had highest number of seven seedlings which was observed in the market sample collected from Vijayawada. Among the collections of Dharwad and surrounding areas $37 \%$ had single seedlings followed by $36.2 \%$ of seeds which produced two seedlings lowest of $1.57 \%$ of seeds produced 6 seedlings. The collections of Khanapur and surrounding areas had $62.5 \%$ with single seedlings, $23 \%$ produced 2 seedlings per seed and $2 \%$ of seeds produced four and five seedlings. Biligiri Rangana betta (B. R.Hills) a natural habitat of Jamun where collections were made from the wild had $46.75 \%$ of the seeds with single seedlings, $31.78 \%$ had two seedlings and $1.87 \%$ of seeds produced 5 seedlings per seed. Srisailam another natural habitat for Jamun at Nallamalai forest zone of Eastern Ghats, Andhra Pradesh also had $44.33 \%$ of the seeds with single seedlings, $26.80 \%$ with two seedlings and $1.03 \%$ with five seedlings per 
seed. The accessions collected from Godhra, Gujarat and surrounding areas had $51.35 \%$ with single seedlings, $31.08 \%$ with two seedlings and $0.68 \%$ produced 6 seedlings per seed. The collections made from Varanasi of Uttar Pradesh and its surrounding areas had $59.06 \%$ with single seedlings, $22.58 \%$ had two seedlings and $0.50 \%$ with six seedlings per seed. Collections made from Jabalpur, Madhya Pradesh and surrounding areas produced $47.93 \%$ with one seedling per seed,
$29.59 \%$ with two seedlings per seed and $0.59 \%$ had six seedlings per seed. The collections of Ranchi, Jharkhand and surrounding areas had highest of $77.74 \%$ with single seedlings per seed, $17.31 \%$ with two seedlings and $1.06 \%$ with four seedlings per seed. Among the collections Dharwad collections had highest polyembryonic seeds $(63.0 \%)$ and Ranchi was lowest $(22.26 \%)$ (Table-1).

Fig.1 Variability in the polyembryonic seedlings among different collections
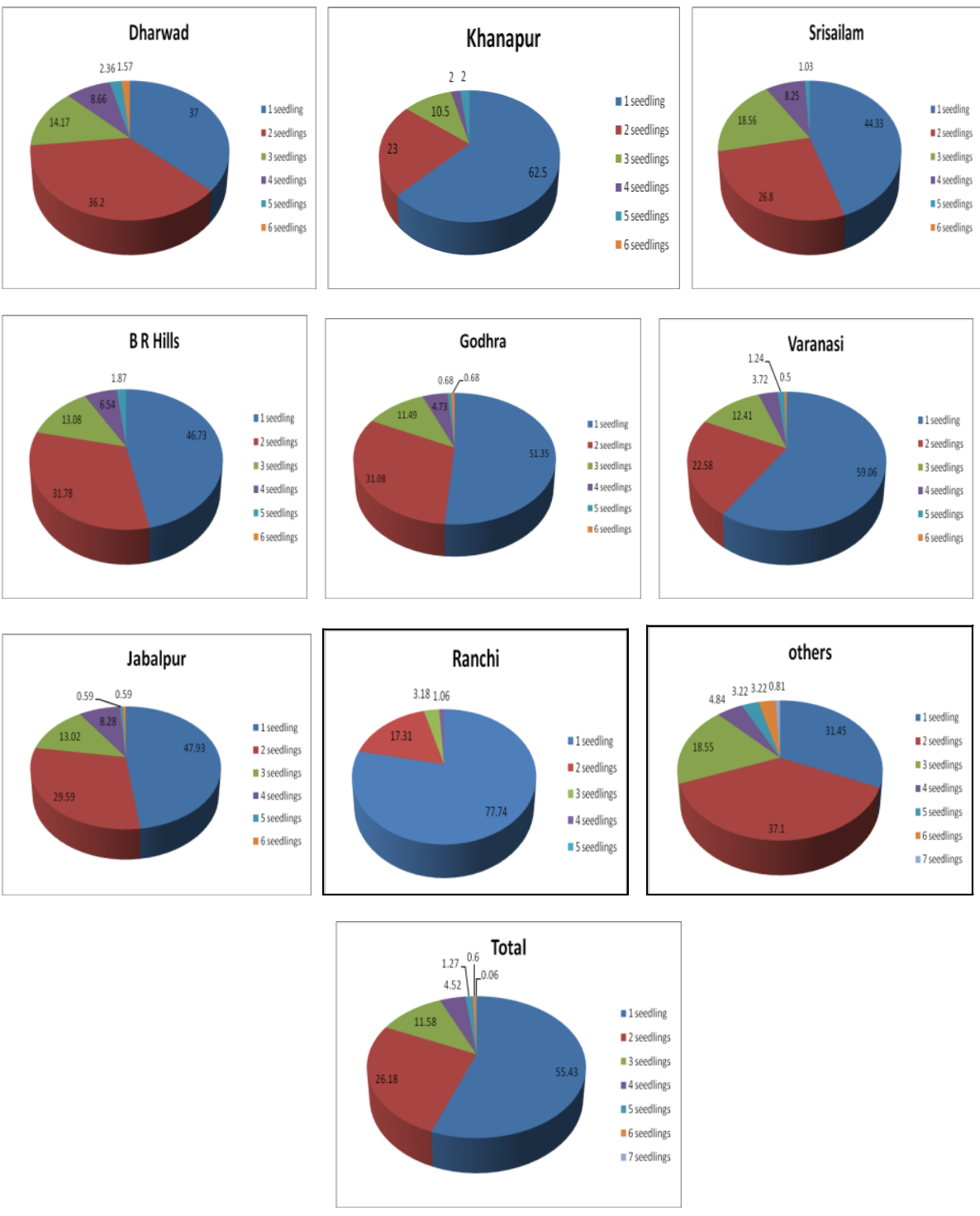
Table.1 Number of seeds sown, seedlings germinated per seed and percent polyembryony

\begin{tabular}{|c|c|c|c|c|c|c|c|c|c|}
\hline $\begin{array}{l}\text { Place of } \\
\text { collection }\end{array}$ & No seeds & $\begin{array}{c}1 \\
\text { seedling }\end{array}$ & $\begin{array}{c}2 \\
\text { seedlings }\end{array}$ & $\begin{array}{c}\mathbf{3} \\
\text { seedlings }\end{array}$ & $\begin{array}{c}4 \\
\text { seedlings }\end{array}$ & $\begin{array}{c}5 \\
\text { seedlings }\end{array}$ & $\begin{array}{c}6 \\
\text { seedlings }\end{array}$ & $\begin{array}{c}7 \\
\text { seedlings }\end{array}$ & $\begin{array}{c}\% \\
\text { polyembryony }\end{array}$ \\
\hline DWR & 127 & 47 & 46 & 18 & 11 & 3 & 2 & None & 63.00 \\
\hline KHA & 200 & 125 & 46 & 21 & 4 & 4 & None & None & 37.50 \\
\hline SS & 97 & 43 & 26 & 18 & 8 & 1 & None & None & 55.67 \\
\hline BRH & 107 & 50 & 34 & 14 & 7 & 2 & None & None & 53.27 \\
\hline Godhra & 148 & 76 & 46 & 17 & 7 & 1 & 1 & None & 48.65 \\
\hline Varanasi & 403 & 238 & 91 & 50 & 15 & 5 & 2 & None & 40.94 \\
\hline JBP & 169 & 81 & 50 & 22 & 14 & 1 & 1 & None & 52.07 \\
\hline Ranchi & 283 & 220 & 49 & 9 & 3 & None & None & None & 22.26 \\
\hline Others & 124 & 39 & 46 & 23 & 6 & 4 & 4 & 1 & 68.55 \\
\hline Total seeds & 1658 & 919 & 434 & 192 & 75 & 21 & 10 & 1 & 43.98 \\
\hline
\end{tabular}

DWR: Dharwad; KHA: Khanapur; SS: Srisailam; BRH: B.R.Hills; JBP: Jabalpur; Others: FRLHT, Ramagondanahalli, Kolar, Nagaland and Vijayawada.

Table.2 Correlation between polyembryony and seed traits

\begin{tabular}{|c|c|c|c|c|}
\hline Particular & SG & SL & SW & PP \\
\hline SG & 1.00000 & & & \\
\hline SL & $0.813(<.0001)$ & 1.00000 & & \\
\hline SW & $0.762(<.0001)$ & $0.782(<.0001)$ & 1.00000 & \\
\hline PP & $0.258(0.1345)$ & $0.252(0.1444)$ & $0.529(0.0011)$ & 1.00000 \\
\hline
\end{tabular}


The correlation studies among the seed parameters were done. Percent polyembryony was positively and significantly correlated but weakly with seed length $(\mathrm{r}=0.258, \mathrm{p}=0.001)$ and seed girth $(\mathrm{r}=0.258, \mathrm{p}=0.001)$. Seed weight and percent polyembryony were positively associated with each other, but were not significantly correlated $(r=0.529$, $\mathrm{p}=0.134)$.

The results indicate that the number of embryos in a seed may not be dependent on seed length and seed girth with very weak correlations between them (Table-2). Though moderate positive correlation has been found between percent polyembryony and seed weight, there seems to be moderate influence of seed weight on polyembryony in addition to other external factors such as genotype and the prevailing microclimate that influence number of viable embryos within the seed. It has been observed that jamun flower has multiple ovules but only one seed develops into the fruit which is single seeded berry (Arathi et al., 1996).

The above results show that there are multiple reasons for polyembryony, moreover seed germination and number of seedlings depends on the environmental factors also. Hence it is difficult to identify the zygotic and nucellar seedlings based on the morphological characters alone. There is a need to use specific molecular markers to identify the zygotic or nucellar seedlings and to assess the rate of nucellar seedlings, for its use as root stock in the nursery or multiplication of selected accessions through seeds and seedlings.

\section{Acknowledgments}

The authors are thankful to Director ICARIIHR for providing the facilities and encouragement. Special thanks to Dr. Linta Vincent for helping with statistical analysis.

\section{References}

Aleza, P., Juárez, J., Ollitrault, P. and Navarro, L. 2010. Polyembryony in non-apomictic citrus genotypes. Annals of Bot, 106:533-545.

Arathi, H. S., Ganeshaiah, K. N., Uma Shaanker, R. and Hegde S. G. 1996. Factors affecting embryo abortion in Syzygium cuminii (L.) Skeels (Myrtaceae). Int. J. Plant Sci. 157(1):49-52. DOI: 1058-5893/96/57010006.

Ensign, M.R. 1919. Venation and Senescence of Polyembryonic Citrus Plants. Amer. J. Bot., 6(8):311-329.

URL: http://www.jstor.org/stable/2435208

Kishore, K. (2014). Polyembryony. In: Ramawat, K. (Ed.), Mérillon, J.M. (Ed.), Shivanna, K. (Ed.). Chapter 15- Reproductive Biology of Plants. Boca Raton: CRC Press. Pp 355-370

Lakshmanan, K.K. and Ambegaokar K.B. 1984. Polyembryony. In: Johri B.M. (eds) Embryology of Angiosperms. Springer, Berlin, Heidelberg.

Maheswari, P. and Sacher, R.C. 1963. Polyembryony. In Recent advances in the embryology of Angiosperms (P. Maheswari, ed.). International Society of Plant Morphologists, New Delhi, p.265-296.

Ochoa, E.C.M., Rodriguez, M.A., Rodríguez, M. R. and Monter, A.V. 2012. Identification of zygotic and nucellar seedlings in polyembryonic mango cultivars. Pesq. Agropec. Bras., Brasília, 47(11):1629-1636.

Sivasubramaniam, K. and Selvarani, K. 2012. Viability and vigor of jamun (Syzygium cumini) seeds. Braz. J. Bot., 35(4): 397-400.

Soares Filho, W. dos S., Lee, L.M. and da Cunha Sobinho, A.P. 1995. Influence of pollinators on polyembryony in citrus. Acta Hortic., 403: 256-265. DOI: 10.17660/Acta Hortic.1995.403.45.

Villegas, M.A. and Andrade, R.M. 2008. Poliembrionía, ventajas y oportunida despara la propagación vegetativa. In: Cruz Castillo, J.G.; Lima, P.A.T. (Ed.). Enfoquestecnológicos en la fruticultura. México: Universidad Autónoma Chapingo, p.149-167 


\section{How to cite this article:}

Rekha, A., H. D. Talang and Anuradha Sane. 2020. Assessing Polyembryony among Jamun (Syzygium cumini Skeels.) Collections. Int.J.Curr.Microbiol.App.Sci. 9(02): 658-663. doi: https://doi.org/10.20546/ijcmas.2020.902.081 